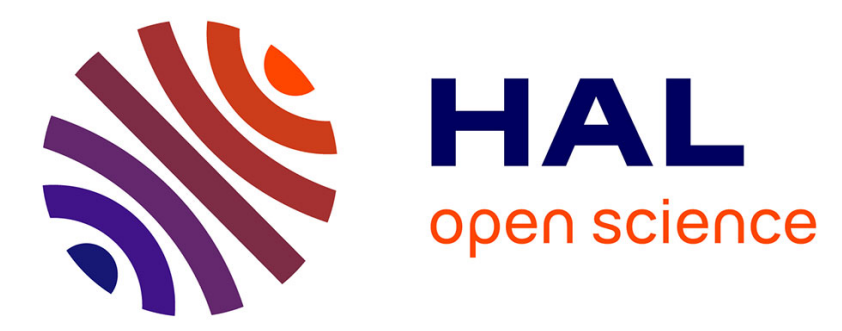

\title{
Photocatalytic degradation of methyl green dye in aqueous solution over natural clay-supported $\mathrm{ZnO}-\mathrm{TiO} 2$ catalysts
}

\author{
Haithem Bel Hadjltaief, Mourad Ben Zina, Maria Elena Galvez, Patrick da
} Costa

\section{To cite this version:}

Haithem Bel Hadjltaief, Mourad Ben Zina, Maria Elena Galvez, Patrick da Costa. Photocatalytic degradation of methyl green dye in aqueous solution over natural clay-supported $\mathrm{ZnO}$ TiO2 catalysts. Journal of Photochemistry and Photobiology A: Chemistry, 2016, 315, pp.25-33. 10.1016/j.jphotochem.2015.09.008 . hal-01206543

\section{HAL Id: hal-01206543 https://hal.sorbonne-universite.fr/hal-01206543}

Submitted on 29 Sep 2015

HAL is a multi-disciplinary open access archive for the deposit and dissemination of scientific research documents, whether they are published or not. The documents may come from teaching and research institutions in France or abroad, or from public or private research centers.
L'archive ouverte pluridisciplinaire HAL, est destinée au dépôt et à la diffusion de documents scientifiques de niveau recherche, publiés ou non, émanant des établissements d'enseignement et de recherche français ou étrangers, des laboratoires publics ou privés. 


\title{
Photocatalytic degradation of methyl green dye in aqueous

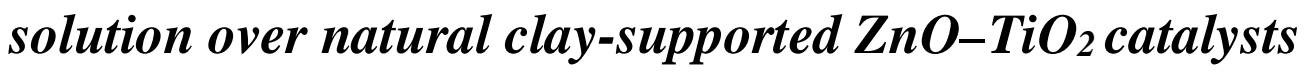

\author{
Haithem BEL HADJLTAIEF ${ }^{1}$, Mourad BEN ZINA ${ }^{1}$, María Elena GÁLVEZ $2,3 *$ \\ elena.galvez_parruca@upmc.fr, Patrick DA COSTA ${ }^{2,3}$,
}

${ }^{1}$ Laboratoire Eau, Energie et Environnement (LR3E), Code: AD-10-02, Ecole Nationale d'Ingénieurs de Sfax, Université de Sfax, B.P1173.W.3038, Sfax, Tunis

${ }^{2}$ UPMC, Univ Paris 06, Sorbonne Universités, Institut Jean Le Rond d'Alembert, 2 place de la Gare de Ceinture, 78210 Saint Cyr l'Ecole, France.

${ }^{3}$ Institut Jean Le Rond d'Alembert, UMR CNRS 7190, 2 place de la Gare de Ceinture, 78210 Saint Cyr l'Ecole, France.

"Corresponding author: Tel.: +3313085 48 77; Fax: +331 308548 99;

Graphical abstract

Schematic illustration of the formation of $\mathrm{ZnO}-\mathrm{TiO} 2 /$ Clay photocatalysts.

\section{Highlights}

- $\mathrm{ZnO}-\mathrm{TiO}_{2} /$ Clay photocatalyst prepared using natural clay

- $\mathrm{ZnO}-\mathrm{TiO}_{2} /$ Clay shows higher activity than $\mathrm{TiO}_{2} / \mathrm{Clay}$ in methyl green degradation

- ZnO has a promoting effect on photocatalytic activity

- Almost omplete mineralization upon 30 min UVA irradiation 


\section{Abstract}

A $\mathrm{ZnO}-\mathrm{TiO}_{2} /$ Clay photcatalyst was prepared using a natural Tunisian clay as support. Its activity was assayed in the photocatalytic degradation of methyl green in aqueous solutions, in the presence of UVA irradiation. The photocatalyst was synthesized using a metal organic chemical vapor deposition (MOCVD) with $\mathrm{Ti}(\mathrm{OPri})^{4}$ deposed on the natural $\mathrm{Na}^{+}-\mathrm{Clay}$, followed by a modified sol-gel synthesis method for introduction. The sample was then characterized by scanning electronic microscopy (SEM), High-resolution transmission electron microscopy (HRTEM), $\mathrm{N}_{2}$ adsorption, X-ray diffraction (XRD) and titration for the determination of the zero point charge $\left(\mathrm{pH}_{\mathrm{ZPC}}\right)$. The activity tests showed that the photodegradation efficiency for $\mathrm{ZnO}-\mathrm{TiO}_{2} /$ Clay is higher than for the $\mathrm{TiO}_{2} /$ Clay catalyst, clearly pointing to a promoting effect of $\mathrm{ZnO}$. The influence of operational parameters such as $\mathrm{pH}$, catalyst dosage, initial dye concentration, UV irradiation intensity, as well as the influence of the presence of different oxidants was evaluated. Almost complete mineralization was obtained upon 30 min of light irradiation in the presence of the $\mathrm{ZnO}-\mathrm{TiO}_{2} /$ Clay catalyst.

\section{Keywords}

Methyl green, Water treatment, Tunisian $\mathrm{Clay}, \mathrm{TiO}_{2}, \mathrm{ZnO}$, Photodegradation, Heterogeneous photocatalyst 


\section{Introduction}

Organic dyes represent an important source of environmental contamination, since they are toxic and mostly non-biodegradable [1]. Conventional treatment methods, such as biodegradation, adsorption flocculation-coagulation, electro-coagulation and conventional chemical oxidation, are not effective enough in achieving complete removal of these organic compounds from industrial wastewaters [2]. Therefore, different advanced oxidation processes, AOPs, have been developed in the last decades in order to boost the oxidation of recalcitrant pollutants, through the generation of highly reactive hydroxyl radicals $(\bullet \mathrm{OH})[3-$ $6]$.

Among the different AOPs, heterogeneous semiconductor photocatalysis has been recently presented as a promising technology allowing the total mineralization of different refractory organic compounds, in the presence of either natural or artificial light. Titanium dioxide $\left(\mathrm{TiO}_{2}\right)$ is one of the most commonly used materials for photocatalytic applications due to its high chemical stability, low cost, low toxicity, and excellent oxidation properties $[4,5] . \mathrm{TiO}_{2}$ is a semiconductor with a bandgap energy range of $3-3.2 \mathrm{eV}$, depending on its crystalline structure (rutile or anatase) $[4,5] . \mathrm{TiO}_{2}$ fine powders such as DEGUSSA P25 have been commercially available for several years. Nevertheless, the photocatalyst must still be removed from the treated suspension though an additional separation step that represents an important drawback towards the practical application of these processes [4]. In order to avoid this separation step, the photocatalytically active phase (e.g. $\left.\mathrm{TiO}_{2}\right)$ can be immobilized on the surface of an structured support. Different materials such as silica [7], perlite [8], fly ash [9], zeolites [10] activated carbons [11,12] and clays [13-16] have been used with this purpose. Among them, clays and clay-based materials represent a highly promising alternative due to their high mechanical and chemical stability, high surface area and high adsorption capacity 
[13-15]. Moreover clays are environmental friendly, low-cost and offer an interesting route for the revalorization of local resources.

Doping or surface modification by transition metals is considered one of the most efficient methods in reducing electron-hole recombination [6, 17-24]. The metal on the surface of the photocatalyst can act as a trap site for the photo-generated electrons, which can prevent electron-hole recombination, and thereby improve photocatalytic activity. For instance, Zhang and co-workers prepared a novel $\mathrm{SnO}_{2}-\mathrm{TiO}_{2}-\mathrm{Clay}$ synthesized by attachment of $\mathrm{SnO}_{2}-\mathrm{TiO}_{2}$ oxides onto the surface of the clay (palygorskite, attapulgite) by in situ sol-gel technique. Compared with origin clay and pure $\mathrm{TiO}_{2}$, these materials exhibited considerably higher photocatalytic activity in the photodecomposition of phenol and methyl orange in water solution [21,22]. In a subsequent work [24], Zhang et al. reported the preparation of a magnetically recoverable $\mathrm{TiO}_{2}-\mathrm{Fe}_{\mathrm{x}} \mathrm{O}_{\mathrm{y}}$ composite loaded onto the surface of attapulgite. This material showed significant photocatalyticactivity in the degradation of methyl orange (MO) under visible light irradiation. Enhanced activity was attributed to the modification of the electronic energy band structure of $\mathrm{TiO}_{2}$ in the presence of nearby $\mathrm{Fe}_{\mathrm{x}} \mathrm{O}_{\mathrm{y}}$, resulting in extended photocatalytic absorbance in the visible light region. $\mathrm{ZnO}$ can be as well used as a promoter of photocatalytic activity. In fact, bulk systems containing $\mathrm{ZnO}$ have been deeply studied in the last decade [25-29]. However, only few and recent works focus on the preparation of $\mathrm{TiO}_{2}-\mathrm{ZnO}$ supported heterogeneous catalyst for the photocatalytic degradation of organic pollutants in wastewaters [30-32]. Among them, $\mathrm{TiO}_{2}-\mathrm{ZnO} / \mathrm{BC}$ composites exhibited a high photocatalytic activity and could remove humic acids from water efficiently under visible light irradiation [30]. To date, the use of $\mathrm{ZnO}$-promoted $\mathrm{TiO}_{2}$ systems supported on clays has been never considered.

In the present study, a natural Tunisian clay was used as the matrix for the immobilization of $\mathrm{TiO}_{2}$ and $\mathrm{ZnO}$. These compounds were loaded on the clay surface by 
means of in-situ metal organic chemical vapor deposition (MOCVD) and via sol-gel synthesis, respectively. The photocatalytic activity of this clay-supported $\mathrm{ZnO}$-promoted $\mathrm{TiO}_{2}$ was assayed in the oxidation of methyl green (MG) dicationic dye. The influence of key operational parameters, such as $\mathrm{pH}$, catalyst dosage, initial dye concentration, oxidant type $\left(\mathrm{H}_{2} \mathrm{O}_{2}, \mathrm{~K}_{2} \mathrm{~S}_{2} \mathrm{O}_{8}, \mathrm{Na}_{2} \mathrm{CO}_{3}\right)$, has been as well considered.

\section{Experimental}

\subsection{Raw materials and reagents}

A natural clay from the Jebel Tejera-Esghira deposits located in the Southeast of Tunisia (Medenine) was used in this study. This natural clay was first purified by dispersion in water, decantation and extraction of the fraction with a particle size smaller than $2 \mu \mathrm{m}$, and subsequently modified through sodium ion-exchange, as carefully described in previous works $[14,33]$. Titanium (IV)-isopropoxide, $\left(\mathrm{Ti}\left(\mathrm{OPr}^{\mathrm{i}}\right)_{4}, \mathrm{TTIP}, 97 \%\right)$, zinc acetate dehydrate $\left(\mathrm{Zn}\left(\mathrm{CH}_{3} \mathrm{COO}\right)_{2} \cdot 2 \mathrm{H}_{2} \mathrm{O} \geq 98 \%\right)$ and Methyl Green dye (MG, cationic, C.I. 42000, chemical formula $\mathrm{C}_{23} \mathrm{H}_{25} \mathrm{~N}_{2} \mathrm{Cl}, \mathrm{FW}=364.91 \mathrm{~g} / \mathrm{mol}$ ) were used without further purification.

\subsection{Preparation of the photocatalysts}

The $\mathrm{TiO}_{2} /$ Clay photocatalyst was prepared following a metal organic chemical vapor deposition method (MOCVD), in a similar way to the procedure reported by Omri et al. [11]. The desired amount $(4.0 \mathrm{~g})$ of the ion-exchanged $\mathrm{Na}^{+}-$Clay (particle size $<63 \mathrm{~mm}$ ) was introduced in a quartz reactor, and dehydrated under a stream of dry nitrogen at $400^{\circ} \mathrm{C}$ for $3 \mathrm{~h}$. Then, the temperature of the reactor was raised to $600{ }^{\circ} \mathrm{C}$. Once the temperature was stable, the vapor deposition of $\mathrm{TiO}_{2}$ was initiated through the evaporation of TTIP contained in a flask at $100^{\circ} \mathrm{C}$, under a nitrogen flow of $200 \mathrm{~mL} / \mathrm{min}$ for $5 \mathrm{~h}$. The gas line was heated to prevent TTIP condensation. At the end of the deposition, the reactor was purged with nitrogen for about $15 \mathrm{~min}$. 
$\mathrm{ZnO}-\mathrm{TiO}_{2} /$ Clay was synthesized via an optimized sol-gel route [34]. $4.38 \mathrm{~g}$ of dehydratedzinc acetate were dissolved in $100 \mathrm{ml}$ of ethanol and stirred in a water bath at $50^{\circ} \mathrm{C} .2 .98 \mathrm{~g}$ of tri-ethanol amine were subsequently added to the solution while stirring was continued for $1 \mathrm{~h}$. The mixture was then placed under vibration and heated for $0.5 \mathrm{~h}$ at $40^{\circ} \mathrm{C}$, resulting in a colorless and transparent sol. At this instant, $3 \mathrm{~g}$ of $\mathrm{TiO}_{2} / \mathrm{Clay}$ were added to this sol. The suspension was further agitated under vibration for another $0.5 \mathrm{~h}$, filtered, dried and calcined for $4 \mathrm{~h}$ at $300^{\circ} \mathrm{C}$.

\subsection{Characterization of the photocatalysts}

In order to determine the structure and morphology of $\mathrm{ZnO}-\mathrm{TiO}_{2} / \mathrm{Clay}, \mathrm{TiO}_{2} / \mathrm{Clay}$ and the original clay were examined by scanning electronic microscopy (SEM, Hitachi SU-70) and high-resolution transmission electron microscopy (HRTEM, JEOL JEM 2011 equipped with LaB6 filament). The HRTEM images were collected with a $4008 \times 2672$ pixel CCD camera (GatanOrius SC1000) coupled with the DIGITAL MICROGRAPH software. Coupled chemical analyses were obtained by an EDX microanalyzer (PGT IMIX PC). Nitrogen adsorption-desorption isotherms for the different materials were acquired at $-196{ }^{\circ} \mathrm{C}$ on a Micromeritics ASAP 2010, after out gassing $\left(10^{-5} \mathrm{~Pa}\right)$ for $24 \mathrm{~h}$ at ambient temperature. Surface areas were calculated using the BET equation, whereas mean pore size, pore size distribution and pore volume were estimated using the BJH method. X-ray diffraction patterns (XRD) were acquired in a Philips-PW 1710 diffractometer $(\mathrm{CuK} \alpha, 40 \mathrm{kV} / 40 \mathrm{~mA}$, scanning rate 2 degree/min). Crystal sizes were calculated through X-ray line broadening analysis using Scherrer equation. The relative content of anatase and rutile, was estimated using SpurrMyers equation [11]. The zero point charge $\left(\mathrm{pH}_{\mathrm{ZPC}}\right)$ of the prepared materials was determined following the method described by Bouzid et al. [35]. 


\subsection{Photocatalytic tests}

The photocatalytic experiments were carried out in a static quartz reactor $(500 \mathrm{~mL})$, equipped with a cold finger to avoid thermal reactions. A UV-A lamp ( $\lambda_{\max }=365 \mathrm{~nm}$, BlackRay B $100 \mathrm{~W}$ UV-lamp, V-100AP series) was placed next to the reactor, at $30 \mathrm{~cm}$ of the liquid surface. In each experiment, $1 \mathrm{~g}$ of photocatalyst was added into $250 \mathrm{~mL}$ of $\mathrm{MG}$ solution $(75 \mathrm{mg} / \mathrm{L}, \mathrm{pH}=5.2)$. Before illumination, the dispersion was magnetically stirred for $20 \mathrm{~min}$ (in the dark), in order to ensure adsorption equilibrium between the photocatalyst surface and the organic dye.

The influence of the $\mathrm{pH}$ of the initial solution was evaluated at $\mathrm{pHs}$ from 2.5 to 10 (adjusted using $\mathrm{HCl}(0.1 \mathrm{M})$ and $\mathrm{NaOH}(0.1 \mathrm{M})$ ), while $\mathrm{MG}$ concentration was fixed at 75 $\mathrm{mg} / \mathrm{L}$, for $1 \mathrm{~g} / \mathrm{L}$ of $\mathrm{ZnO}-\mathrm{TiO}_{2} /$ Clay photocatalyst. Catalyst dosage was varied from 0.1 to 2 $\mathrm{g} / \mathrm{L}$, for $75 \mathrm{mg} / \mathrm{L}$ of $\mathrm{MG}$ solution, at $\mathrm{pH}=6.32$. The influence of the $\mathrm{MG}$ dye concentration was also evaluated by varying its concentration from $25 \mathrm{mg} / \mathrm{L}$ to $150 \mathrm{mg} / \mathrm{L}$, at a fixed $\mathrm{pH}$ of 6.32 , in the presence of $0.8 \mathrm{~g}$ of $\mathrm{ZnO}-\mathrm{TiO}_{2} /$ Clay photocatalyst. $8 \mathrm{~mL}$ of $\mathrm{H}_{2} \mathrm{O}_{2}, \mathrm{~K}_{2} \mathrm{~S}_{2} \mathrm{O}_{8}$ or $\mathrm{Na}_{2} \mathrm{CO}_{3}$ (prepared from $250 \mathrm{mg} / \mathrm{L}$ of $\mathrm{H}_{2} \mathrm{O}_{2}(35 \%), \mathrm{K}_{2} \mathrm{~S}_{2} \mathrm{O}_{8}(98 \%)$ or $\mathrm{Na}_{2} \mathrm{CO}_{3}(98 \%)$ ) were added into the reaction solution just before switching on the light, with the aim of assaying the influence of the presence of an oxidizing agent, or, in the case of $\mathrm{Na}_{2} \mathrm{CO}_{3}$ as a way to buffer the solution $\mathrm{pH}$ into basic values.

The stability of the $\mathrm{ZnO}-\mathrm{TiO}_{2} /$ Clay photocatalyst was assayed by means of performing five consecutive experiments by using fresh $75 \mathrm{mg} / \mathrm{L}$ MG solutions, at $\mathrm{pH} 6.32$ and $0.8 \mathrm{~g} / \mathrm{L}$ catalyst. Between each experiment, the photocatalyst was removed by filtration, carefully washed with distilled, and dried at $110{ }^{\circ} \mathrm{C}$ for $12 \mathrm{~h}$.

Solution aliquots were periodically withdrawn from the reaction vessel with the aid of a syringe and at predetermined intervals. Upon filtration using a $0.45 \mu \mathrm{m}$ membrane, the dye 
concentration was determined in a Shimadzu 160A UV-visible spectrophotometer, at the maximal adsorption wavelength of $\mathrm{MG}, \lambda_{\max }=632 \mathrm{~nm}$.

The decolorization efficiency was calculated as follows (1):

$$
R(\%)=\left(1-\left(\frac{A_{t}}{A_{0}}\right)\right) \times 100
$$

where, $A_{0}$ represents the initial absorbance of the $M G$ solution, and $A_{t}$ its absorbance after $t$ minutes of irradiation/reaction.

Chemical oxygen demand (COD) was determined using the reactor digestion method based on the method of acidic oxidation by bichromate.

\subsection{Physico-chemical characterization}

The SEM micrographs acquired for the raw and the modified clays are presented in Fig. 1. Upon $\mathrm{TiO}_{2}$ addition, the surface morphology of the $\mathrm{Na}^{+}-$exchanged clay changes significantly (Fig.1 a vs. Fig. 1 b). The unloaded clay presents large particle aggregates with smooth surfaces whereas after MOCVD of Ti isopropoxide, an homogeneous distribution of $\mathrm{TiO}_{2}$ grains completely covers the surface of the original clay. The $\mathrm{ZnO}-\mathrm{TiO}_{2} /$ Clay catalyst,

Fig 1. c, shows the spongelike surface with $\mathrm{ZnO}$ particles covering the $\mathrm{TiO}_{2}$ structures. TEM images further confirm these changes in the morphology of the different materials (Fig. 2). $\mathrm{ZnO}$ and $\mathrm{TiO}_{2}$ nanocomposites are observed on to the surface of the clay, with an average particle size was about $10 \mathrm{~nm}$.

The X-ray diffraction patterns for $\mathrm{Na}^{+}-\mathrm{Clay}$, $\mathrm{TiO}_{2} /$ Clay and $\mathrm{ZnO}-\mathrm{TiO}_{2} /$ Clay are shown in Fig. 3. The typical diffraction peaks of quartz, kaolinite and illite are evidenced in the spectrum acquired for the clay, pointing to their presence as the main crystalline phases [14, 36]. The XRD patterns of $\mathrm{TiO}_{2} /$ Clay catalyst show the appearance of peaks at $2 \theta$ angles of $25.3^{\circ}, 37.9^{\circ}, 48.4^{\circ}, 55.3^{\circ}$ and $62.7^{\circ}$ corresponding to the (101), (103), (200), (105) and (213) 
crystalline planes of its anatase form [12, 14, 16, 24] (JCPDS Card No. 21-1272). Upon ZnO loading, new peaks are observed pointing to the presence of a $\mathrm{ZnO}$ zincite phase in the $\mathrm{ZnO}-\mathrm{TiO}_{2} /$ Clay material $\left(2 \theta=31.8,34.4,36.2,47.5,56.6,62.9\right.$ and $67.9^{\circ}$ corresponding to (100), (002), (101), (102), (110), (103) and (112) reflections, JCPDS Card No. 001-1136. The diffraction peaks at $25 .^{\prime} \circ, 37.9^{\circ}, 48.376^{\circ}, 55.3^{\circ}$ and $62.7^{\circ}$ correspond to the (101), (103), (200), (105) and (213) planes of anatase [37, 38], JCPDS Card No. 21-1272. Other peaks mainly at $27.2^{\circ}$ can be assigned to (101) diffraction planes of rutile, JCPDS No. 21-1272 [39].

The relative content of anatase and rutile was estimated using Spurr-Myers equation [40]:

$$
A(\%)=\frac{I_{A}}{I_{A}+1,265 \times I_{R}} \times 100
$$

Where $\mathrm{A}(\%)$ is the relative content of anatase, $\mathrm{I}_{\mathrm{A}}$ and $\mathrm{I}_{\mathrm{R}}$ are the intensities of the anatase (101) peak at $2 \theta=25.3^{\circ}$ and the rutile (101) peak at $2 \theta=27.2^{\circ}$. The anatase content of $\mathrm{ZnO}-\mathrm{TiO}_{2} / \mathrm{Clay}$ around $97 \%$ points to the predominant presence of this phase in the prepared photocatalyst. Anatase content further increases upon the addition of $\mathrm{ZnO}$.

The crystal size of $\mathrm{TiO}_{2}$ was calculated from the XRD profiles using the DebyeScherrer equation. The average sizes of $\mathrm{TiO}_{2}$ crystallite in the catalyst are listed in Table 1 . Crystal sizes around $17 \mathrm{~nm}$ were found to be independent of the presence of $\mathrm{ZnO}$ in the photocatalyst composition.

Table 1 contains as well the values of surface area, pore volume and mean pore diameter calculated from the corresponding nitrogen adsorption isotherms acquired for each material. The specific surface area increases substantially as a consequence of $\mathrm{TiO}_{2}$ loading, i.e. from $37 \mathrm{~m}^{2} / \mathrm{g}$ in the $\mathrm{Na}^{+}-$Clay to $105 \mathrm{~m}^{2} / \mathrm{g}$ in the $\mathrm{ZnO}-\mathrm{TiO}_{2} /$ Clay. This increase in surface area is due to the creation of a porous $\mathrm{TiO}_{2}$ phase on the clay surface. Pore volume slightly decreases upon $\mathrm{ZnO}$ incorporation to the catalyst, pointing to a slight pore blockage of the 
$\mathrm{TiO}_{2}$ surface. Figure 4 contains the $\mathrm{N}_{2}$ adsorption isotherms as well as the $\mathrm{BJH}$ pore size distributions calculated for the different materials.

Figure 5 shows evolution of $\Delta \mathrm{pH}$, i.e., $\left(\mathrm{pH}_{0}-\mathrm{pH}_{\mathrm{f}}\right)$ as a function of $\mathrm{pH}$ during $\mathrm{pH}$ measurements. The zero point charnge for the $\mathrm{TiO}_{2}$ Clay and $\mathrm{ZnO}-\mathrm{TiO}_{2} / \mathrm{Clay}$ were found to be 7.4 and 6.4 , respectively.

\subsection{Catalytic activity in the decolorization of Methyl Green solutions}

The photocatalytic activity in the decolorization of MG for the different materials is shown in Figure 6. Under dark reaction conditions, about $29 \% ; 25 \%$ and $18 \%$ decolorization was measured respectively for $\mathrm{ZnO}-\mathrm{TiO}_{2} / \mathrm{Clay}, \mathrm{TiO}_{2} /$ Clay and the parent $\mathrm{Na}^{+}-$clay, from a $100 \mathrm{mg} / \mathrm{L} \mathrm{MG}$ solution after $20 \mathrm{~min}$ irradiation. This can be simply assigned to the adsorption of the dye organic molecule on the materials' surface, since it is in complete agreement with the increase of surface area upon $\mathrm{TiO}_{2}$ and $\mathrm{ZnO}$ loading. Photolysis of $\mathrm{MG}$ under $\mathrm{UV}$ irradiation in absence of any photocatalyst results in negligible MG degradation for $60 \mathrm{~min}$. In the presence of UV light and either $\mathrm{ZnO}-\mathrm{TiO}_{2} / \mathrm{Clay}, \mathrm{TiO}_{2} / \mathrm{Clay}$ or the $\mathrm{Na}^{+}-$clay, $98.7 \%$, $87.2 \%$ and $32.6 \%$ decolorization were respectively measured 60 minutes irradiation. The enhanced photocatalytic activity of $\mathrm{ZnO}-\mathrm{TiO}_{2} / \mathrm{Clay}$ can be attributed to the increased presence of anatase in its composition [41], together with the positive influence of $\mathrm{ZnO}$ acting as a promoter of the photocatalytic activity, by means of extending the adsorption of the incident radiation $[29,30]$. The preparation procedure results in separated $\mathrm{TiO}_{2}$ and $\mathrm{ZnO}$ phases that enhance the adsorption of the incident irradiation and avoiding the combination of electron-hole pairs through a one-way charge transfer mechanism [29].

\subsection{Influence of operational parameters}


The photocatalytic activity is strongly affected by the surface charge properties of the material, the charge of the molecule, the adsorption of the organic molecule on the photocatalyst surface and on the concentration of hydroxyl radicals [30, 42-45]. All these properties are $\mathrm{pH}$ dependent. Therefore $\mathrm{pH}$ is an important operational parameter determining the efficiency of the photocatalytic removal of different pollutants in wastewaters. The effect of varying $\mathrm{pH}$ from 3 to 10 in the initial MG solution is shown in Fig. 7, for an initial MG concentration of $75 \mathrm{mg} / \mathrm{L}$, over $\mathrm{ZnO}-\mathrm{TiO}_{2} /$ Clay $(1 \mathrm{~g} / \mathrm{L})$, and under $\mathrm{UV}$ irradiation. The decolorization efficiency of MG increases significantly, i.e. from $32.1 \%$ to almost $100 \%$, upon an increase in solution $\mathrm{pH}$ from 2.8 to 6.32 . Decolorization efficiency decreases with a further increase in $\mathrm{pH}$, proving that the $\mathrm{pH}$ of the dye solution determines the adsorption of the organic compound on the surface of $\mathrm{ZnO}-\mathrm{TiO}_{2} /$ Clay and represents an important reaction step in the overall mechanism of dye oxidation [46]. Adsorption and thus dye degradation seem to be favored at $\mathrm{pH}$ around the zero point charge $\mathrm{pH}\left(\mathrm{pH}_{\mathrm{zpc}}\right)$, i.e. 6.4 for the $\mathrm{ZnO}-$ $\mathrm{TiO}_{2} /$ Clay is. At a $\mathrm{pH}$ lower than 6.4 the surface of $\mathrm{ZnO}-\mathrm{TiO}_{2} /$ Clay photocatalyst is positively charged, whereas at $\mathrm{pH}$ higher than 6.4 it becomes negatively charged. Since MG is a dicationic type dye, a $\mathrm{pH}$ higher than that corresponding to the zero point charge favors the adsorption of MG molecule on the catalyst surface which results in enhanced degradation of MG under neutral and basic conditions. However, a further increase in $\mathrm{pH}$ leads to an increase coulombic repulsion between the negative charged $\mathrm{ZnO}-\mathrm{TiO}_{2} / \mathrm{Clay}$ surface and the $\mathrm{OH}^{-}$species involved in the photocatalytic oxidation mechanism [47], leading to decreased degradation efficiency.

Fig. 8 shows the influence of the catalyst dosage on the decolorization efficiency. When the amount of the catalyst is increased in the range $0.1-0.8 \mathrm{~g} / \mathrm{L}$, the decolorization efficiency increases from $32 \%$ to almost $100 \%$ after 60 min of irradiation time. This is due to the increase in the catalyst concentration and thus of the amount of sites available for 
absorption of photons and dye molecules. However, further increasing the catalyst dosage from 0.8 to $2.0 \mathrm{~g} / \mathrm{L}$ resulting in a slight decrease in the decolorization efficiency. Excess of catalyst leading to substantial particle agglomeration may explain this fact, as previously described in the existing literature $[16,48]$. Moreover, a more concentrated catalyst suspension may lead to decrease of its transparency resulting in less efficient radiation penetration.

In view of the practical application of the photocatalytic process in the presence of the $\mathrm{ZnO}-\mathrm{TiO}_{2} / \mathrm{Clay}$ catalyst, the influence of dye concentration on the degradation efficiency must be analyzed [14, 49, 50]. Decolorization efficiency was then measured during the photocatalytic degradation of MG solutions at different concentrations from 25 to $150 \mathrm{mg} / \mathrm{L}$. Results are presented in Fig. 9. As the concentration of MG in the initial solution increases, longer irradiation times are needed for attaining the same decolorization efficiency.

The data plotted in Fig. 9 were used for the calculation of the apparent kinetic constants for different reaction conditions. The rate of degradation of organic compounds in wastewaters can be described by a pseudo-first order Langmuir-Hinshelwood kinetic model:

$$
r=-\frac{d \tau}{d t}=\frac{c k k_{r}}{1+K C}
$$

Where $r$ stands for the rate of degradation, $\mathrm{K}$ represents the equilibrium constant for the adsorption of MG on the catalyst surface, and $k_{r}$ denotes the kinetic constant for the degradation reaction at maximum surface coverage.

On integrating Equation (3), we obtain the irradiation time, t, for attaining a concentration $\mathrm{C}_{\mathrm{t}}$ of the pollutant:

$$
t=\left(\frac{1}{k_{k}}\right) \ln \left(\frac{C_{0}}{C_{t}}\right)+\frac{c_{0}-C_{t}}{k_{r}}
$$


Where $\mathrm{C}_{0}$ represents the initial concentration of MG. Therefore at low $\mathrm{C}_{0}$, the second term in Equation (4) becomes insignificant and hence can be neglected:

$$
\ln \left(\frac{c_{0}}{C_{t}}\right)=k_{r} K t=k_{a p p} t
$$

With $\mathrm{k}_{\mathrm{app}}$ as the apparent rate constant for the photocatalytic degradation reaction.

The almost perfect linearity of the $\ln \left(\mathrm{C}_{0} / \mathrm{C}_{\mathrm{t}}\right)$ versus $t$ plots for various initial $\mathrm{MG}$ concentrations, Fig. 10, proves the applicability of the Langmuir-Hinshelwood equation for the photocatalytic degradation of MG. The apparent rate constant, $\mathrm{k}_{\mathrm{app}}$, decreases as the initial concentration of MG increases. At too high MG concentrations, a greater amount of dye molecules adsorb on the catalyst surface blocking the photocatalytically active sites on the catalyst, thus reducing the absorption of photons, their interaction with the active sites and therefore inhibiting the photocatalytic degradation process. In addition, increasing $\mathrm{MG}$ concentration leads to a larger fraction of the UV irradiation that is absorbed by the dye molecules in the water solution, instead of being absorbed by the catalytically active sites [16, $47,48]$.

Several works in the existing literature point to the addition of oxidants as an efficient way of improving the photodegradation of organic pollutants in waste waters $[14,47,48]$. The influence of the presence of different oxidizing agents such as hydrogen peroxide $\left(\mathrm{H}_{2} \mathrm{O}_{2}\right)$, and potassium peroxodisulfate $\left(\mathrm{K}_{2} \mathrm{~S}_{2} \mathrm{O}_{8}\right)$, together with sodium carbonate $\left(\mathrm{Na}_{2} \mathrm{CO}_{3}\right)$ as $\mathrm{pH}$ buffer, on the degradation of MG was studied at an initial $\mathrm{pH}$ of 6.32 , on a $100 \mathrm{mg} / \mathrm{L}$ of dye solution and in the presence of 0.8 g.L $\mathrm{L}^{-1}$ of the $\mathrm{ZnO}-\mathrm{TiO}_{2} / \mathrm{Clay}$ catalyst. Table 2 contains the decolorization efficiency measured after $60 \mathrm{~min}$ irradiation in the presence of the different oxidants. As expected, the addition of these compounds enhances the photodegradation of MG. This is due to the photo-activated formation of $\bullet \mathrm{OH}, \mathrm{SO}_{4} \bullet$ and $\mathrm{CO}_{3} \bullet / \mathrm{HCO}_{3} \bullet$ radicals during reaction that contribute to faster dye oxidation. Among the three oxidants assayed, 
$\mathrm{H}_{2} \mathrm{O}_{2}$ was found to be the most efficient in enhancing the degradation of $\mathrm{MG}$, followed by $\mathrm{K}_{2} \mathrm{~S}_{2} \mathrm{O}_{8}$ and $\mathrm{Na}_{2} \mathrm{CO}_{3}$. Note that the effect of $\mathrm{Na}_{2} \mathrm{CO}_{3}$ may be rather assigned to a basification of the reaction $\mathrm{pH}$, or even to a catalytic effect in the presence of sodium ions [49].

\subsection{Mineralization}

UV-vis absorption spectra of the dye solution were acquired at different reaction timed and are presented in Figure 11. The degradation experiment was performed at $\mathrm{pH}=6.3$, $75 \mathrm{mg} / \mathrm{L}$ dye concentration, $0.6 \mathrm{~g} / \mathrm{L}$ of $\mathrm{ZnO}-\mathrm{TiO}_{2} /$ Clay photocatalyst. The initial Methyl green (MG) solution UV-visible spectra presents four absorption peaks the prominent peak at $632 \mathrm{~nm}$ and other peaks at $420 \mathrm{~nm}, 315 \mathrm{~nm}$ and smaller peak at $256 \mathrm{~nm}$. The peak at $632 \mathrm{~nm}$ decreases gradually by the addition of $\mathrm{ZnO}-\mathrm{TiO}_{2} / \mathrm{Clayand}$ disappears within $30 \mathrm{~min}$. The decrease of the sample's absorbance intensity at its $\lambda_{\max }=632 \mathrm{~nm}$ is indicated by the photodegradation of the dye in the applied conditions. As a consequence the decrease of samples absorbance due to decrease of the dye concentration was recorded for measurement of photodegradation rate in all above-mentioned parameters. Since there are no additional peaks appearing in the UV-vis spectra the dye is thus completely degraded. The percentages of COD reduction measured are presented in Table 2. These values point to almost complete mineralization even in the absence of oxidant, i.e. upon $30 \mathrm{~min}$ irradiation, $100 \%$ decolorization is achieved corresponding to a percentage of COD reduction of $89.3 \%$. Using $\mathrm{H}_{2} \mathrm{O}_{2}$ as oxidant leads to faster and more efficient mineralization than when using the two other chemical agents.

\subsection{Stability of the $\mathrm{ZnO}-\mathrm{TiO}_{2} /$ Clay photocatalyst}

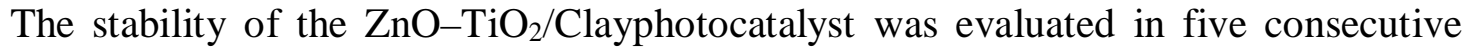
experiments by using fresh MG solutions at concentration of $75 \mathrm{mg} / \mathrm{L}, \mathrm{pH} 6.3$, and $0.8 \mathrm{~g} / \mathrm{L}$ 
catalyst. Between each experiment, the photocatalyst was removed by filtration, then washed with distilled water several times, and dried at $110{ }^{\circ} \mathrm{C}$ for $12 \mathrm{~h}$.

Degradation efficiency of the Methyl Green by $\mathrm{ZnO}-\mathrm{TiO}_{2} /$ Clayphotocatalyst was still higher than $95 \%$ after being used in the three subsequent cycles. The photocatalytic degradation efficiency was $98.3 \%$ during the first 2 cycles (Fig. 12). The photocatalyst activity slightly dropped in runs 4 and 5, resulting in $97.2 \%$ and $95.81 \%$ degradation, respectively. The deactivation of the photocatalyst is likely related to some surface poisoning that may be induced by adsorbed intermediates. We could also note, after analyzing the solutions after runs, that no species coming from catalysts were detected. The experimental observation of Dutta and Ray [50] indicated that strongly adsorbed intermediates occupied the active sites on the catalyst surface and led to a slight loss of photocatalytic activity. As conclusion, this result further proves that $\mathrm{suchZnO}-\mathrm{TiO}_{2} /$ Clay catalysts possess an adequate stability, presenting only small decay in its degradation efficiency.

\section{Conclusions}

$\mathrm{ZnO}-\mathrm{TiO}_{2}$ was successfully supported on a ion exchanged Tunisian clay and used as a photocatalyst for the degradation of methyl green aqueous solutions.

The experimental results indicate that this $\mathrm{ZnO}-\mathrm{TiO}_{2} /$ Clay catalyst shows high photocatalytic activity, higher than the $\mathrm{Na}^{+}$-exchanged clay and $\mathrm{TiO}_{2} / \mathrm{Clay}$, pointing to a positive effect of the presence of $\mathrm{ZnO}$ in the catalytic composition, due to the suitable arrangement of their respective valence and conduction bands, favoring both electron and hole transfer and hindering their recombination. The photodegradation of MG was significantly influenced by the initial $\mathrm{pH}$ of the solution, the catalyst dosage and the initial dye concentration. The addition of oxidants modestly enhanced the degradation rate, since almost 
complete mineralization remains possible in the single presence of the $\mathrm{ZnO}-\mathrm{TiO}_{2} / \mathrm{Clay}$ catalyst upon only 30 minutes of irradiation. The Tunisian clay was thus found to be a suitable support for preparing well dispersed and highly active $\mathrm{TiO}_{2}$ and $\mathrm{ZnO}$ phases, showing at the same time good chemical stability through catalyst use.

\section{References}

[1] J.E.B. McCallum, S.A. Madison, S. Alkan, R.L. Depinto, R.U.R. Wahl, Analytical studies on the oxidative degradation of the reactive textile dye Uniblue A, Environmental Science and Technology. 34 (2000) 5157- 5164.

[2] A. Hassani, L. Alidokht, A.R. Khataee, S. Karaca, Optimization of comparative removal of two structurally different basic dyes using coal as a low-cost and available adsorbent, Journal of the Taiwan Institute of Chemical Engineers. 45 (2014) 1597-1607.

[3] H. BelHadjltaief, P, Da Costa, M.E. Galvez, M. Benzina, Influence of operational parameters in the heterogeneous photofenton discoloration of wastewaters in the presence of an iron pillared clay, Industrial \& Engineering Chemistry Research 52 (2013) 16656-16665.

[4] M.R. Hoffmann, S.T. Martin, W. Choi, D.W. Bahnemann, Environmental applications of semiconductor photocatalysis, Chemical Reviews 95 (1995) 69-96.

[5] J.-M. Herrmann, Heterogeneous photocatalysis: fundamentals and applications to the removal of various types of aqueous pollutants, Catalysis Today. 53 (1999) 115-129

[6] D. Chen, Y. Du, H. Zhu, Y. Deng, Synthesis and characterization of a microfibrous $\mathrm{TiO}_{2}-$ $\mathrm{CdS} /$ palygorskite nanostructured material with enhanced visible-light photocatalytic activity, Applied Clay Science 87 (2014) 285-291. 
[7] R. van Grieken , J. Aguado, M.J. López-Muñoz, J. Marugán, Synthesis of size-controlled silica-supported $\mathrm{TiO}_{2}$ photocatalysts Journal of Photochemistry and Photobiology A: Chemistry 148 (2002) 315-322

[8] S.N. Hosseini, S.M. Borghei, M. Vossoughi, N. Taghavinia, Immobilization of $\mathrm{TiO}_{2}$ on perlite granules for photocatalytic degradation of phenol, Applied Catalysis B: Environ. 74 (2007) 53.

[9] C. Li, B. Wang, H. Cui, J. Zhai, Q. Li, Preparation and Characterization of Buoyant Nitrogen-doped $\mathrm{TiO}_{2}$ Composites Supported by Fly Ash Cenospheres for Photocatalytic Applications, Journal of Materials Science and Technology 29 (2013) 835-840

[10] Wang CC, Lee CK, Lyu MD, Juang LC. Photocatalytic degradation of C.I. Basic Violet 10 using $\mathrm{TiO}_{2}$ catalysts supported by $\mathrm{Y}$ zeolite: an investigation of the effects of operational parameters, Dyes and Pigments 2008;76:817-24.

[11] Omri A., S.D. Lambert, J. Geens, F. Bennour, M. Benzina, Synthesis Surface Characterization and Photocatalytic Activity of $\mathrm{TiO}_{2}$ Supported on Almond Shell Activated Carbon, Journal of Materials Science and Technology 30 (2014) 894-902.

[12] A. Omri, M. Benzina, N. Ammar, Preparation, modification and industrial application of activated carbon from almond shell. Journal of Industrial and Engineering Chemistry 19 (2013) 2092-2099.

[13] D. Chen, H. Zhu, X. Wang, A facile method to synthesize the photocatalytic $\mathrm{TiO}_{2} /$ montmorillonite nanocomposites with enhanced photoactivity, Applied Surface Science 319 (2014) 158-166.

[14] H. BelHadjltaief, M.E. Galvez, P, Da Costa, M. Benzina, $\mathrm{TiO}_{2} /$ clay as a heterogeneous catalyst in photocatalytic/photochemical oxidation of anionic reactive blue 19, Arabian Journal of Chemistry (2014) http://dx.doi.org/10.1016/j.arabjc.2014.11.006. 
[15] R. Djellabi, M.F. Ghorab, G. Cerrato c, S. Morandi, S. Gatto, V. Oldani ,A. Di Michele, C.L. Bianch, Photoactive $\mathrm{TiO}_{2}-$ montmorillonite composite for degradation of organic dyes in water, Journal of Photochemistry and Photobiology A: Chemistry 295 (2014) 57-63.

[16] K. Alireza, M. Sheydaei, A. Hassani , M. Taseidifar, S. Karaca, Sonocatalytic removal of an organic dye using $\mathrm{TiO}_{2} /$ Montmorillonitenanocomposite Ultrasonic Sonochemistry 22 (2015) 404-411.

[17] J. Feng, S.K. Raymond, Wong, X, Hu, P. L Yue, Discoloration and mineralization of Orange II by using $\mathrm{Fe}^{3+}$-doped $\mathrm{TiO}_{2}$ and bentonite clay-based $\mathrm{Fe}$ nanocatalysts, Catalysis Today 98 (2004) 441-446.

[18] Y. Jing, C. Feng, Z. Xiaobing, C. ZhigangPreparation, characterization and catalytic oxidation property of $\mathrm{CeO}_{2} / \mathrm{Cu}^{2+}$ - attapulgite (ATP) nanocompositesn, Journal of Rare Earths 28 (2010) 347-352.

[19] K. Chen, J. Li, J.Li, Y. Zhang, W. Wang, Synthesis and characterization of $\mathrm{TiO}_{2}-$ montmorillonites doped with vanadiumand/or carbon and their application for the photodegradation ofsulphorhodamine B under UV-vis irradiation. Colloids and Surfaces A: Physicochem. Eng. Aspects 360 (2010) 47-56.

[20] K. Sahel, M. Bouhent, F. Belkhadem , M. Ferchichi , F. Dappozze , C. Guillard , F. FiguerasPhotocatalytic degradation of anionic and cationic dyes over $\mathrm{TiO}_{2} \mathrm{P} 25$, and $\mathrm{Ti}-$ pillared clays and Ag-doped Ti-pillared clays, Applied Clay Science 95 (2014) 205-210

[21] L. Zhang, Lv. Fujian, W. Zhang, R. Li , H. Zhong, Y. Zhao, Y. Zhang, X. Wang, Photo degradation of methyl orange by attapulgite- $\mathrm{SnO}_{2}-\mathrm{TiO}_{2}$ nanocomposites, Journal of Hazardous Materials 171 (2009) 294-300.

[22] L. Zhang, J. Liu, C. Tang, Lv. Jinshun, H. Zhong, Y.Zhao, X. Wang, Palygorskite and $\mathrm{SnO}_{2}-\mathrm{TiO}_{2}$ for the photodegradation of phenol, Applied Clay Science 51 (2011) 68-73. 
[23] J. Zhang, Lili Zhang, Lv. Jinshun, S. Zhou, H. Chen, Y. Zhao, X. Wang, Exceptional visible-light-induced photocatalytic activity of attapulgite- $\mathrm{BiOBr}-\mathrm{TiO}_{2}$ nanocomposites, Applied Clay Science 90 (2014) 135-140

[24] J. Zhang, L. Zhang, S. Zhou, H. Chen, H. Zhong, Y. Zhao, X. Wang, Magnetically separable attapulgite $\mathrm{TiO}_{2} \mathrm{FexOy}$ composites with superior activity towards photodegradation of methyl orange under visible light radiation, Journal of Industrial and Engineering Chemistry 20 (2014) 3884-3889.

[25] S. Senthilvelan, V.L. Chandraboss, B. Karthikeyan, L. Natanapatham, M. Murugavelu, $\mathrm{TiO}_{2}, \mathrm{ZnO}$ and nanobimetallic silica catalyzed photodegradation of methylgreen, Materials Science in Semiconductor Processing 16 (2013)185-192,

[26] N. Daneshvar, D. Salari, A.R. Khataee, Photocatalytic degradation of azo dye acid red 14 in water on $\mathrm{ZnO}$ as an alternative catalyst to $\mathrm{TiO}_{2}$, Journal of Photochemistry and Photobiology A: Chemistry 162 (2004) 317-322.

[27] N.H.H. Hairom, A.W. Mohammad, A.A.H. Kadhum, Effect of various zinc oxide nanoparticles in membrane photocatalytic reactor for Congo red dye treatment, Separation and Purification Technology 137 (2014) 74-81.

[28] H. Satori, Y. Kawase, Decolorization of dark brown colored coffee effluent using zinc oxide particles: The role of dissolved oxygen in degradation of colored compounds, Journal of Environmental Management 139 (2014) 172-179.

[29] E. Topkaya, M. Konyar, H.C. Yatmaz, K. Öztürk, Pure $\mathrm{ZnO}$ and composite $\mathrm{ZnO} / \mathrm{TiO}_{2}$ catalyst plates: A comparative study for the degradation of azo dye, pesticide and antibiotic in aqueous solutions, Journal of Colloid and Interface Science 430 (2014) 6-11. 
[30] X. Wang, Z. Wu, W. Yin, W. Wang, X .Wang, Y. Bu, J. Zhao, Adsorptionphotodegradation of humic acid in water by using $\mathrm{ZnO}$ coupled $\mathrm{TiO}_{2} /$ bamboo charcoal under visible light irradiation Journal of Hazardous Materials 262 (2013) 16-24.

[31] N. Sapawe, A.A. Jalil, S. Triwahyono, One-pot electro-synthesis of $\mathrm{ZrO}_{2}-\mathrm{ZnO} / \mathrm{HY}$ nanocomposite for photocatalyticdecolorization of various dye-contaminants, Chemical Engineering Journal 225 (2013) 254-265

[32] A. Nezamzadeh-Ejhieh, S. Khorsandi, Photocatalytic degradation of 4-nitrophenol with $\mathrm{ZnO}$ supported nano-clinoptilotite zeolite, Journal of Industrial and Engineering Chemistry 20 (2014) 937-946.

[33] H. BelHadjltaief, P. Da Costa, P. Beaunier, M.E. Galvez, M. Benzina, Fe-clay-plate as a heterogeneous catalyst in photo-Fenton oxidation of phenol as probe molecule for water treatment. Applied Clay Science 91-92(2014) 46-54.

[34] K Abedi, G-S Farshid, B. Jaleh, A. Bahrami, R. Yarahmadi, R. Haddadi, M. Gandomi Decomposition of chlorinated volatile organic compounds (CVOCs) using NTP coupled with $\mathrm{TiO}_{2} / \mathrm{GAC}, \mathrm{ZnO} / \mathrm{GAC}$, and $\mathrm{TiO}_{2}-\mathrm{ZnO} / \mathrm{GAC}$ in a plasma-assisted catalysis system, Journal of Electrostatics 73 (2015) 80-88.

[35] J. Bouzid, Z. Elouear, M. Ksibi, M. Feki, A. Montiel, A study on removal characteristics of copper from aqueous solution by sewage sludge and pomace ashes, Journal of Hazardous Materials 152 (2008) 838-845.

[36] B. Neppolian, H.C. Choi, S. Sakthivel, B. Arabindoo, V. Murugesan, Solar light induced and $\mathrm{TiO}_{2}$ assisted degradation of textile dye reactive blue 4, Chemosphere 46 (2002) 11711181. 
[37] Y. Ao, F. J. D. Xu, X. Shen, C. Yuan, Low temperature preparation of anatase $\mathrm{TiO}_{2}-$ coated activated carbon, Colloids and Surfaces A: Physicochemical and Engineering Aspects, 312 (2008) 125-130.

[38] N.N. Binitha, S. Sugunan, Preparation, characterization and catalytic activity of titania pillared montmorillonite clays. Microp. Mesop. Mater. 93 (2006) 82-89.

[39] S.H. Lin, C.H. Chiou, C.K. Chang, R.S. Juang,. Photocatalytic degradation of phenol on different phases of $\mathrm{TiO}_{2}$ particles in aqueous suspensions under UV irradiation. Journal of Environmental Management 92 (2011) 3098-3104.

[40] R.A. Spurr, H. Myers, H. Quantitative analysis of anatase rutile mixtures with an X-ray diffractometer, Analytical Chemistry 29 (1957) 760-762.

[41] Z. Ambrus, K. Mogyorósi, A. Szalai, T. Alapi, K. Demeter, A. Dombi, A., Sipos. Low temperature synthesis, characterization and substrate-dependent photocatalytic activity of nanocrystalline $\mathrm{TiO}_{2}$ with tailor-made rutile to anatase ratio, Applied Catalysis A: Gen. 340 (2008) 153- 161.

[42] B. Neppolian, H.C. Choi, S. Sakthivel, B. Arabindoo, V. Murugesan, Solar light induced and $\mathrm{TiO}_{2}$ assisted degradation of textile dye reactive blue 4, Chemosphere 46 (2002) 11711181.

[43] A. Nezamzadeh-Ejhieh, E.Shahriari, Photocatalyticdecolorization of methyl green using $\mathrm{Fe}(\mathrm{II})$-ophenanthroline as supported onto zeolite Y, Journal of Industrial and Engineering Chemistry 20 (2014) 2719-2726.

[44] I.K. Konstantinou, T.A. Albanis, $\mathrm{TiO}_{2}$-assisted photocatalytic degradation of azo dyes in aqueous solution: kinetic and mechanistic investigations: a review, Applied Catalysis B: Environ. 49 (2004) 1-14. 
[45] A. Nezamzadeh-Ejhieh, M. Amiri, $\mathrm{CuO}$ supported Clinoptilolite towards solar photocatalytic degradation of p-aminophenol, Powder Technology 235 (2013) 279-288.

[46] V. Kuzhalosai, B. Subash, A. Senthilraja, P. Dhatshanamurthi, M. Shanthi Synthesis, characterization and photocatalytic properties of $\mathrm{SnO}_{2}-\mathrm{ZnO}$ composite under UV-A light, Spectrochimica Acta Part A: Molecular and Biomolecular Spectroscopy 115 (2013) 876-88

[47] A. Jain, A. Ashma, K. Marazban, Expedient Degradation of Dye Methyl Green by Enhanced Photo - Fenton Process: A Green Chemical Approach, Journal of Applied Chemistry 2 (2014) 13-25.

[48] N. Casas, T. Parella, T. Vicent , G. Caminal , M. Sarrà Metabolites from the biodegradation of triphenylmethane dyes by Trametes versicolor or laccase, Chemosphere 75 (2009) 1344-1349.

[49] Arakawa, H. Water Photolysis by $\mathrm{TiO}_{2}$ Particles Significant Effect of $\mathrm{Na}_{2} \mathrm{CO}_{3}$ Addition on Water Splitting. In Photocatalysis Science and Technology; Kaneko, M., Okura, I., Eds.; Springer: New York, 2002; 235-248.

[50] Dutta,K.P., Ray,A.K., Experimental Investigation of Taylor Vortex Photocatalytic Reactor for Water Purification, Chemical Engineering Science 59 (2004) 5249-5259.

\section{Figure Captions}

Fig.1. SEM images for (a) Raw clay (b) $\mathrm{TiO}_{2}-\mathrm{Clay}$ and (c) $\mathrm{ZnO}-\mathrm{TiO}_{2} / \mathrm{Clay}$

Fig.2. TEM images and EDS spectra for (a) Raw clay (b) $\mathrm{ZnO}-\mathrm{TiO}_{2} / \mathrm{Clay}$

Fig.3. XRD patterns for the raw clay, $\mathrm{TiO}_{2} /$ Clay and $\mathrm{ZnO}-\mathrm{TiO}_{2} / \mathrm{Clay}$

Fig.4. $\mathrm{N}_{2}$ adsorption isotherms and BJH pore size distribution calculated for the different materials

Fig.5. pHzpc for the $\mathrm{TiO}_{2} / \mathrm{Clay}$ and $\mathrm{ZnO}-\mathrm{TiO}_{2} /$ Clay photocatalyst 
Fig.6. Photocatalytic decolorization of MG solutions in absence and in the presence of the $\mathrm{Na}^{+}$-clay, the $\mathrm{TiO}_{2} /$ Clay and $\mathrm{ZnO}-\mathrm{TiO}_{2} /$ Clay catalysts, $[\mathrm{MG}]_{0}=75 \mathrm{mg} \cdot \mathrm{L}^{-1}$, [catalyst $]_{0}=1$ $\mathrm{g} \cdot \mathrm{L}^{-1} \mathrm{pH}=6.32, \mathrm{~T}=25^{\circ} \mathrm{C}$

Fig.7. Influence of initial solution $\mathrm{pH}$ on the decolorization efficiency $\left([\mathrm{MG}]_{0}=75 \mathrm{mg} \cdot \mathrm{L}^{-1}\right.$, [catalyst $\left.]=1 \mathrm{~g} \cdot \mathrm{L}^{-1}, \mathrm{~T}=25^{\circ} \mathrm{C}\right)$

Fig.8. Influence of catalyst dosage on the decolorization efficiency, $[\mathrm{MG}]_{0}=75 \mathrm{mg} \cdot \mathrm{L}^{-1}, \mathrm{pH}$ $=6.32, \mathrm{~T}=25^{\circ} \mathrm{C}$,

Fig.9. Influence of dye concentration on decolorization efficiency, [catalyst] $=0.8 \mathrm{~g} \cdot \mathrm{L}^{-1}, \mathrm{pH}=$ $6.32, \mathrm{~T}=25^{\circ} \mathrm{C}$,

Fig.10. Pseudo-first order kinetics plots. Inset shows rate constants for the photocatalytic degradation of MG. [catalyst] $=0.8 \mathrm{~g} \cdot \mathrm{L}^{-1}, \mathrm{pH}=6.32, \mathrm{~T}=25^{\circ} \mathrm{C}$.

Fig.11. Evolution of UV-vis spectra acquired at different stages of the photocatytic treatment Fig.12. Decolorization efficiency through five consecutive catalyst reuse cycles. 


\section{Tables}

Table 1 Textural and structural properties of the ion-exchanged and the $\mathrm{TiO}_{2}$-photocatalysts.

\begin{tabular}{|c|c|c|c|c|c|c|c|}
\hline Catalyst & $\begin{array}{c}\boldsymbol{S}_{\text {BET }} \\
\left(\boldsymbol{m}^{2} / \mathbf{g}\right)\end{array}$ & $\begin{array}{c}\text { Pore } \\
\text { volume } \\
\left(\mathbf{c m}^{3} / \mathbf{g}\right)\end{array}$ & $\begin{array}{c}\text { Mean } \\
\text { pore size } \\
(\mathbf{n m})\end{array}$ & $\begin{array}{c}\mathrm{TiO}_{2} \text { crystal } \\
\text { size }(\mathbf{n m})\end{array}$ & $\begin{array}{c}\text { Anatase } \\
\text { content } \\
(\%)\end{array}$ & $\begin{array}{c}\mathrm{TiO}_{2} \\
\text { content } \\
(\%)\end{array}$ & $\begin{array}{c}\text { ZnO } \\
\text { content } \\
(\%)\end{array}$ \\
\hline $\mathrm{Na}^{+}$-Clay & 36.6 & 0.131 & 1.2 & - & - & - & - \\
\hline $\mathrm{TiO}_{2}$ Clay & 113.1 & 0.255 & 3.5 & 16.9 & 94.2 & 17.8 & - \\
\hline $\begin{array}{c}\mathrm{ZnO}- \\
\mathrm{TiO}_{2} / \mathrm{Clay}\end{array}$ & 105.1 & 0.196 & 3.6 & 16.8 & 97.1 & 16.7 & 11.0 \\
\hline
\end{tabular}

Table 2. Influence of the presence of the different oxidants on degradation of MG in the presence of $\mathrm{ZnO}-\mathrm{TiO}_{2} / \mathrm{Clay}$ under UV irradiation.

\begin{tabular}{|c|c|c|c|}
\hline Activity test & Time (min) & $\boldsymbol{R}(\%)$ & \% of COD reduction \\
\hline No oxidant & 30 & 100 & 89.3 \\
\hline $\mathrm{H}_{2} \mathrm{O}_{2}$ & 17 & 100 & 98.9 \\
\hline $\mathrm{K}_{2} \mathrm{~S}_{2} \mathrm{O}_{8}$ & 20 & 100 & 88.4 \\
\hline $\mathrm{Na}_{2} \mathrm{CO}_{3}$ & 36 & 100 & 75.6 \\
\hline
\end{tabular}


Fig.1.
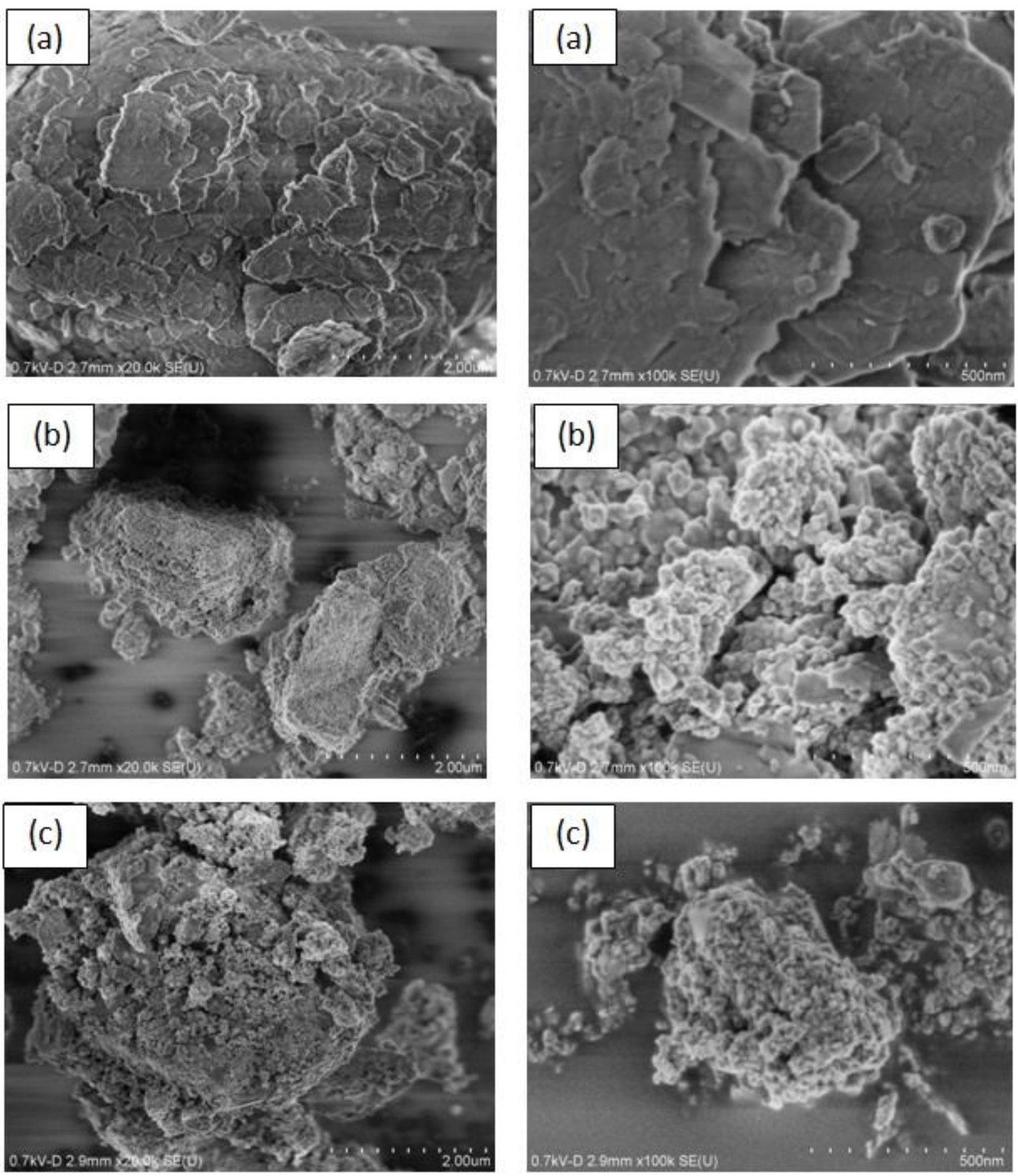
Fig.2.
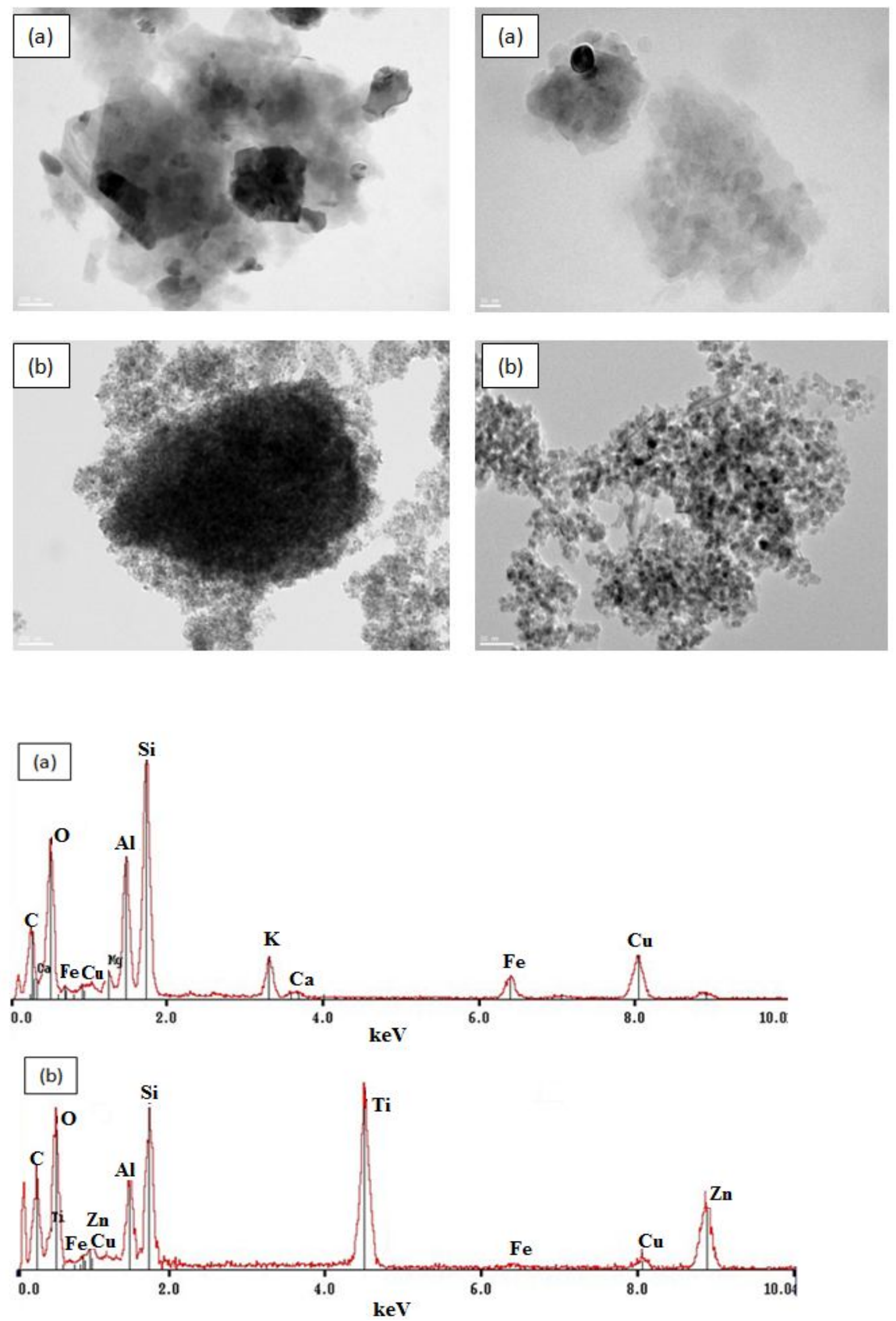
Fig. 3.

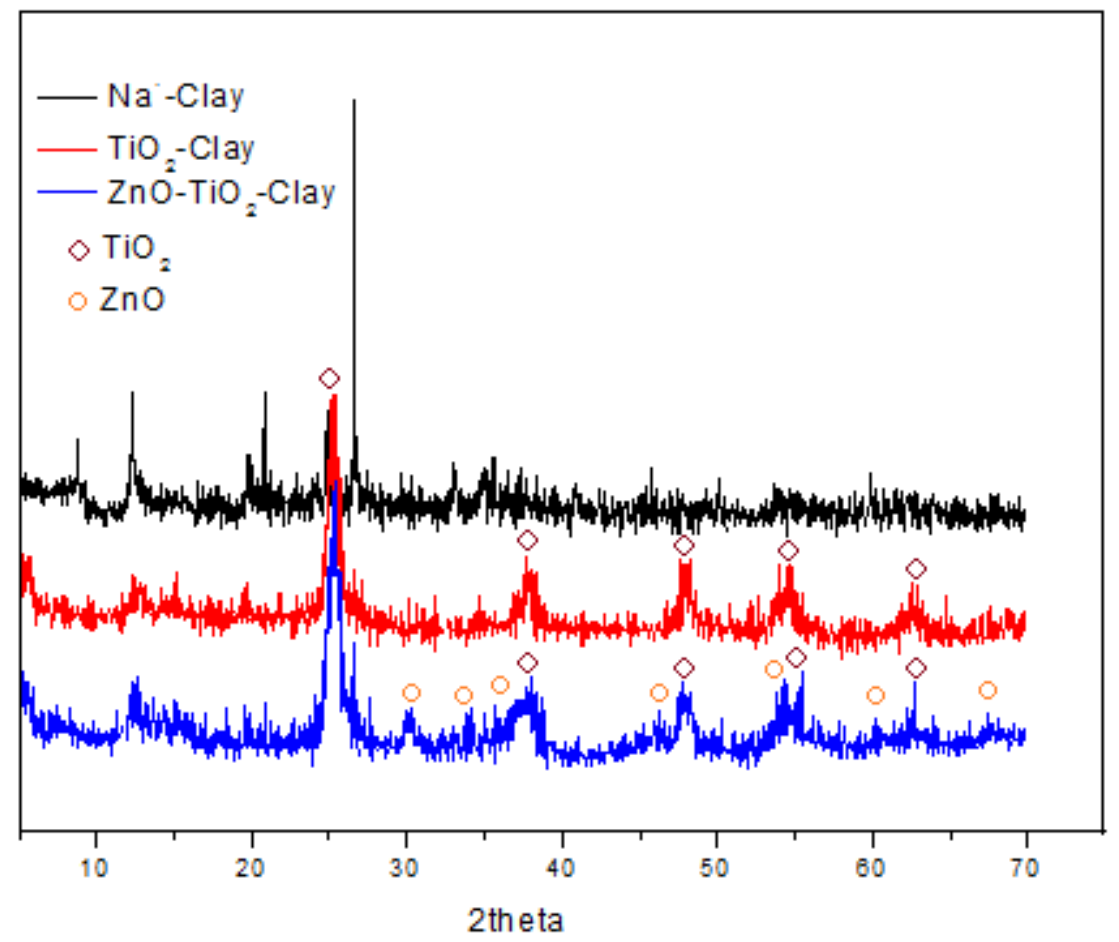

Fig.4.

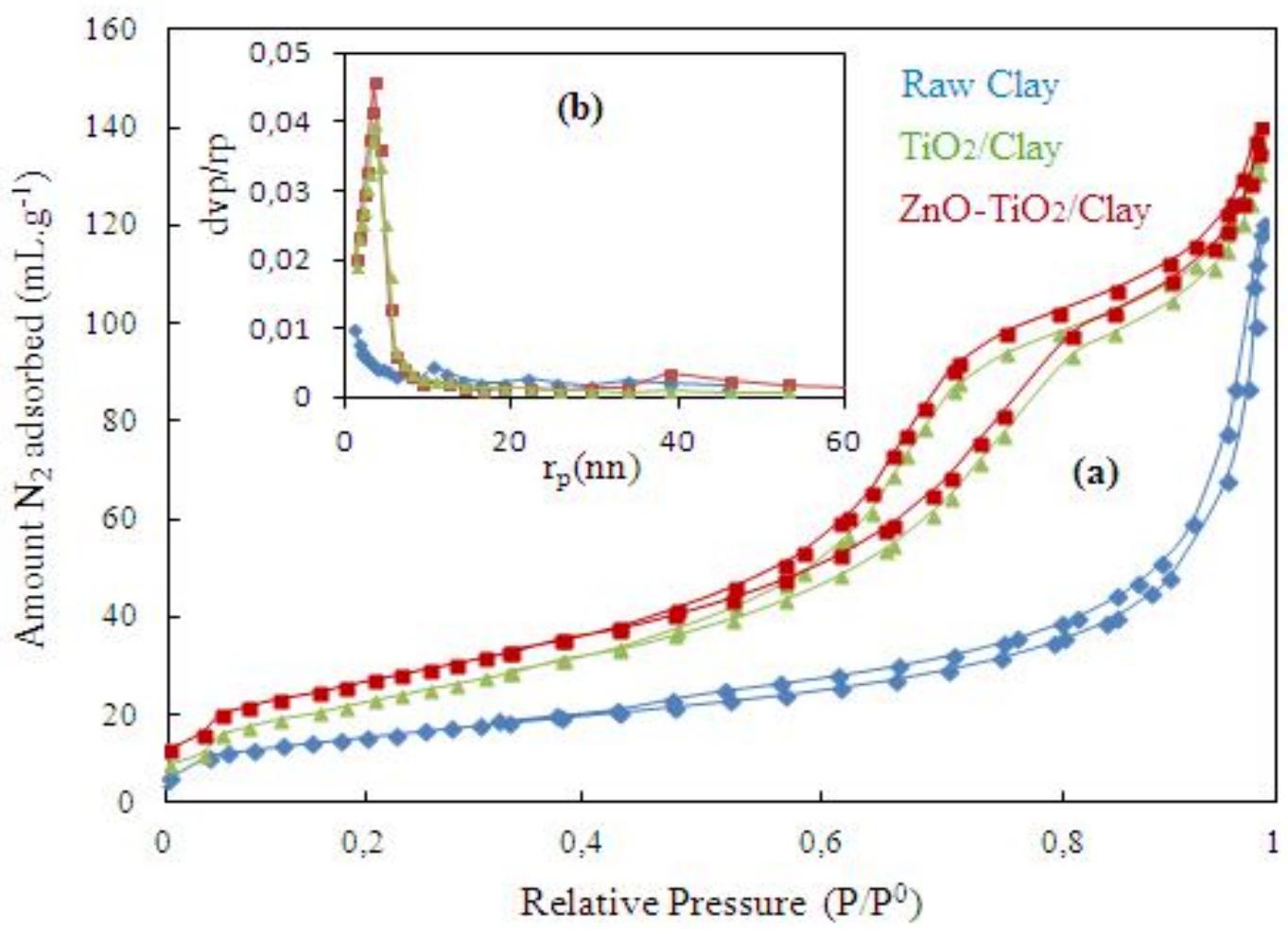


Fig.5.

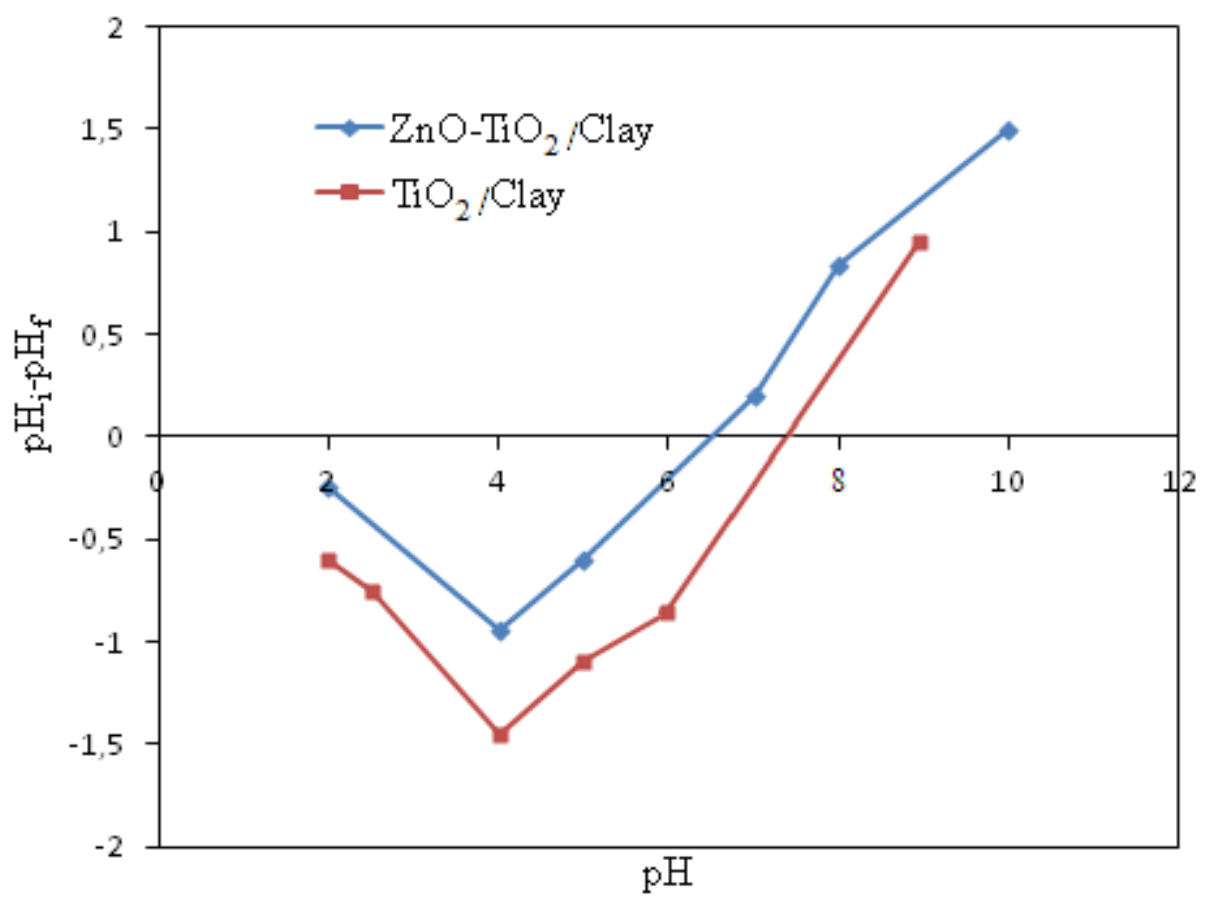

Fig.6.

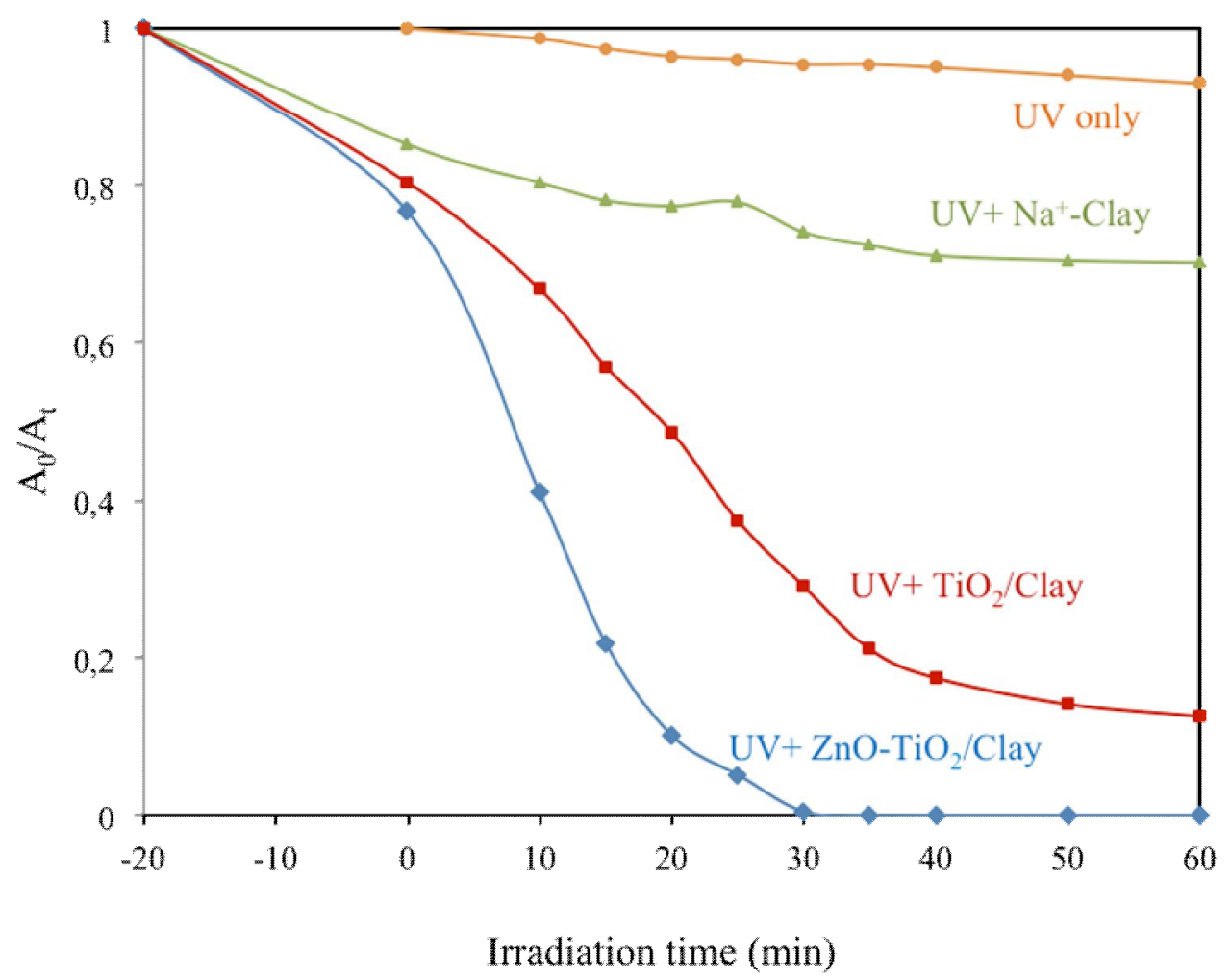


Fig.7.

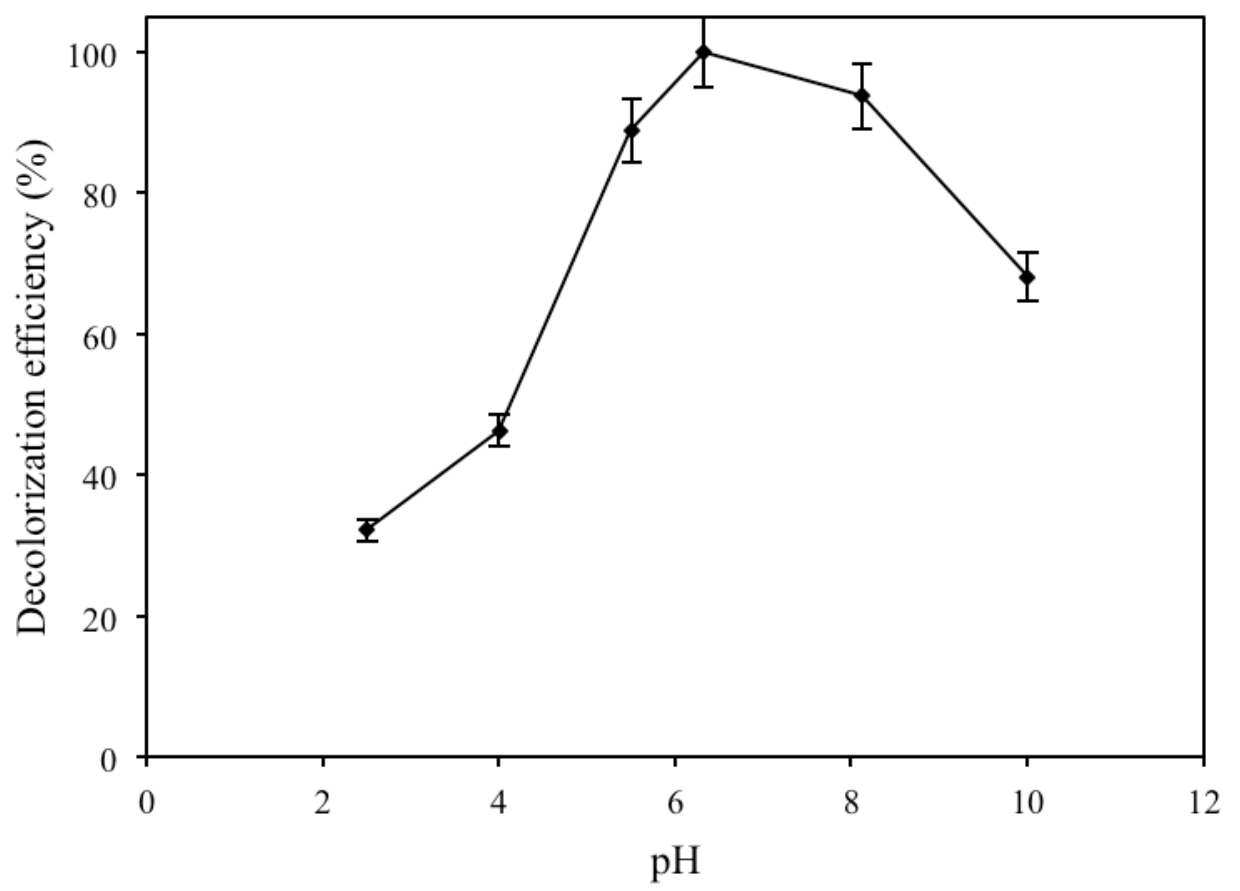

Fig.8.

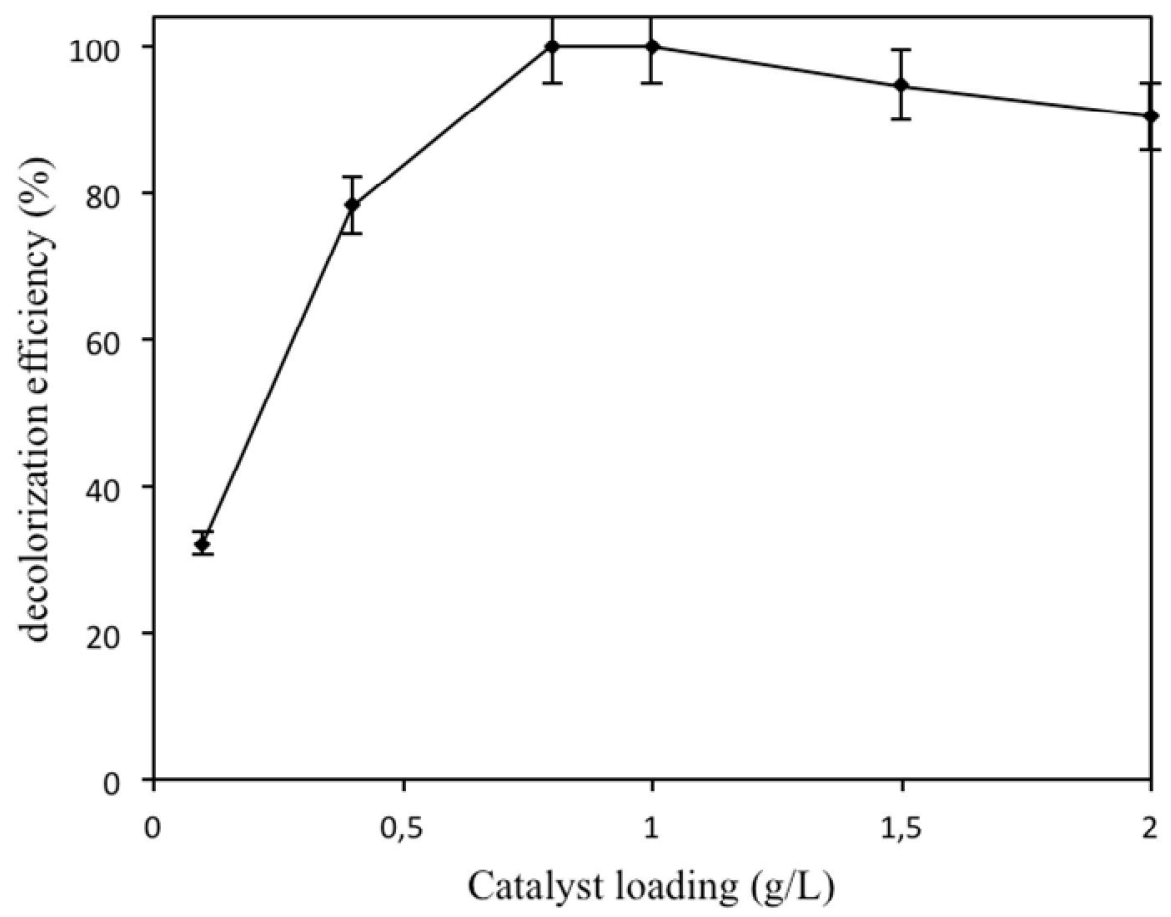


Fig.9.

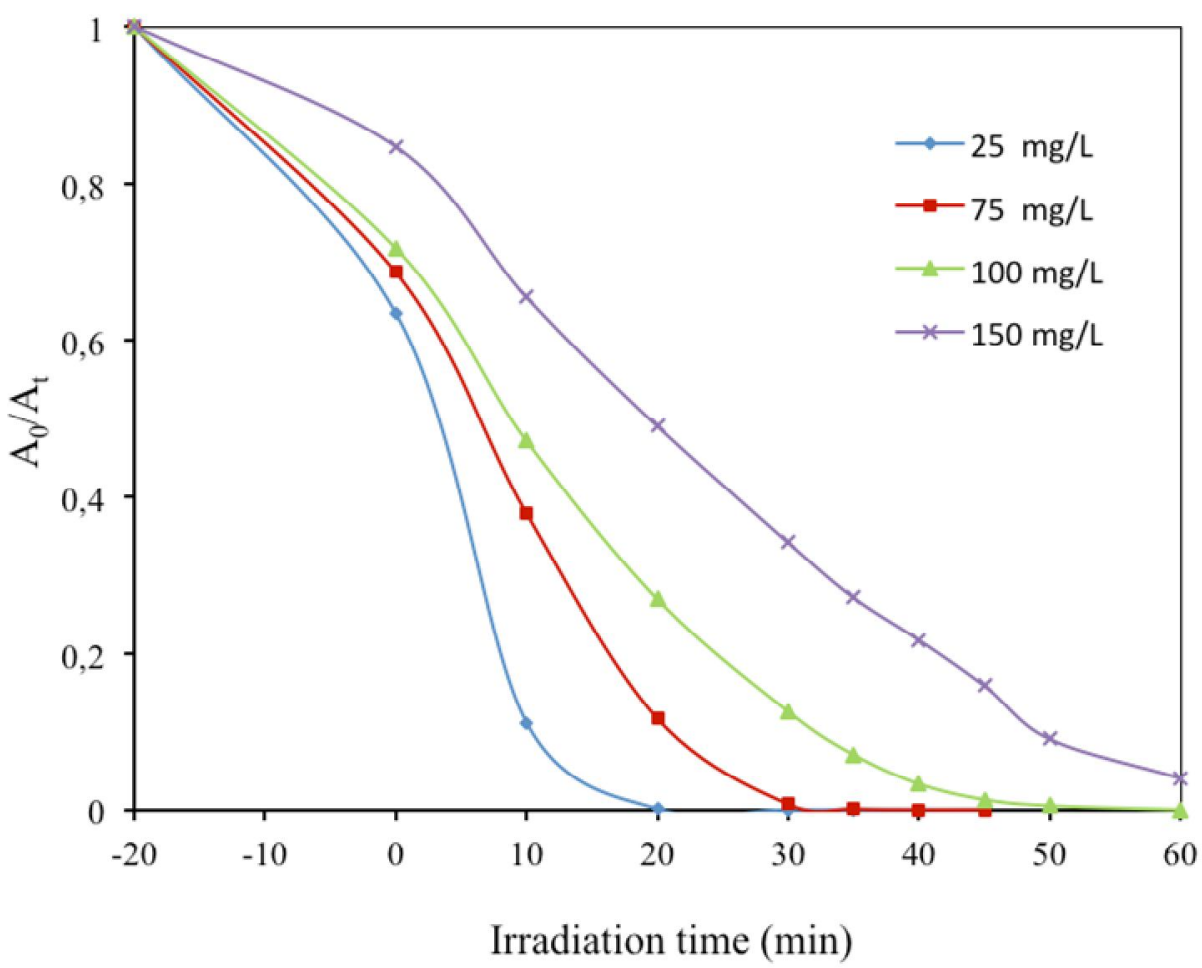

Fig.10.

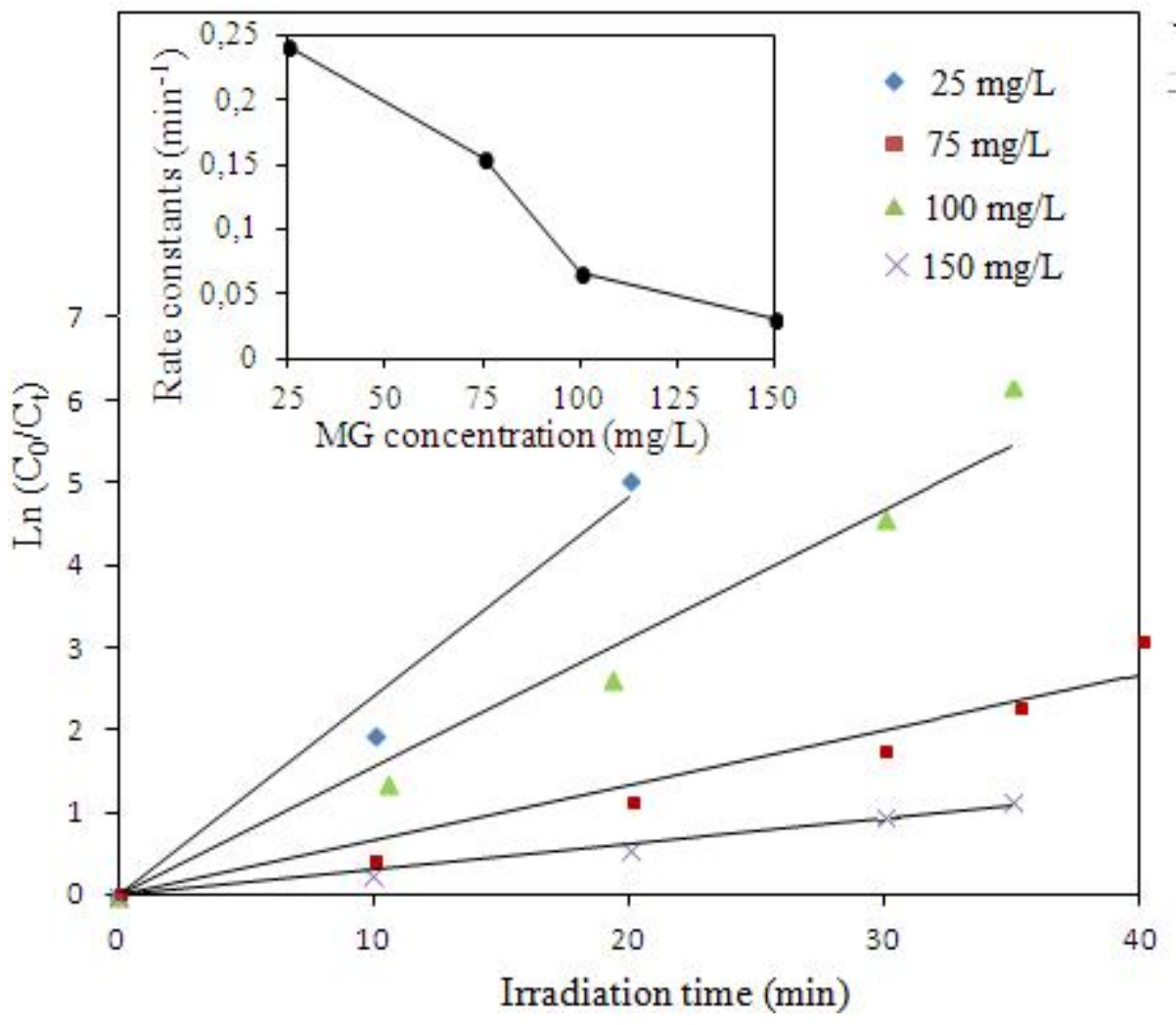


Fig.11.

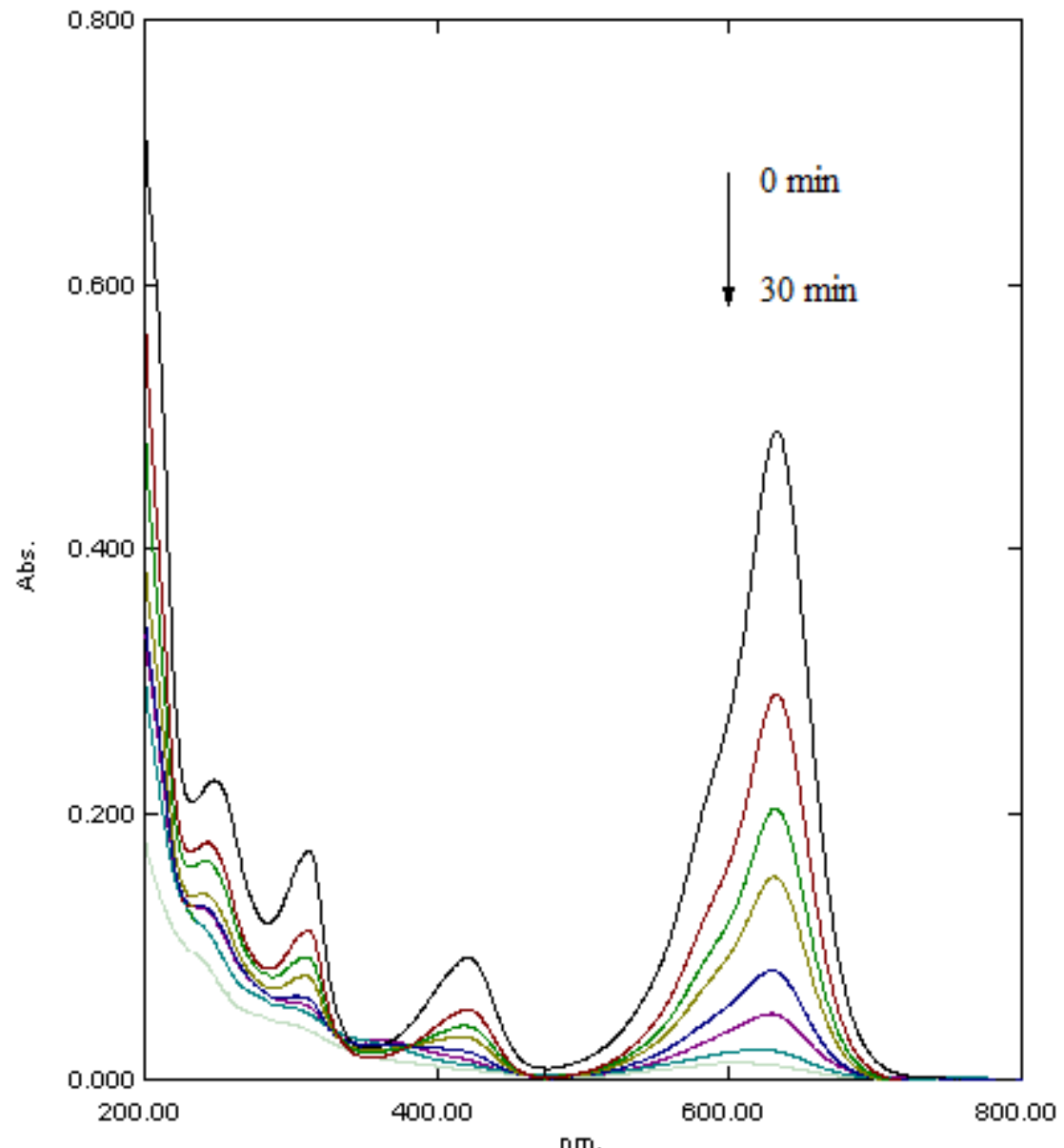


Fig. 12.

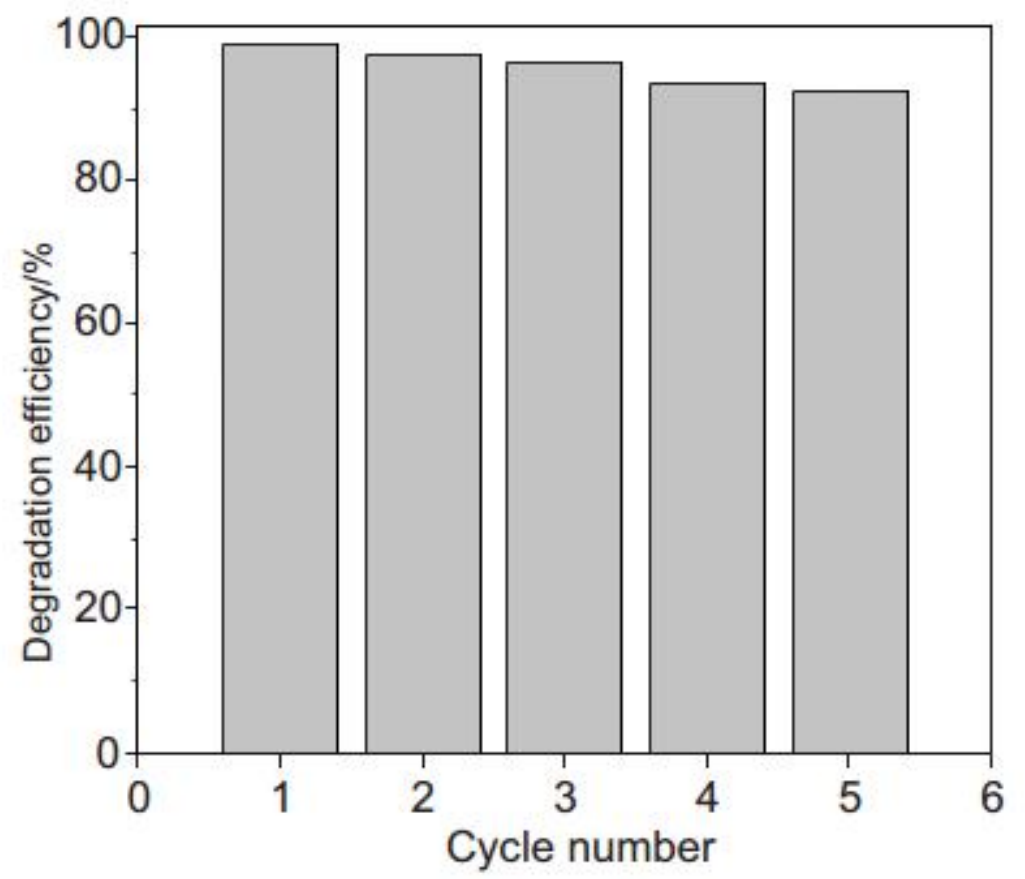

